\title{
Challenges in Inclusive Mathematics Education: Representations by Professionals Who Teach Mathematics to Students with Disabilities
}

\author{
Geraldo Eustáquio Moreira' ${ }^{1}$ Ana Lúcia Manrique ${ }^{2}$ \\ ${ }^{1}$ Department of Education, Federal University of Goiás, Goiânia, Brazil \\ ${ }^{2}$ Program of Mathematics Education, Pontifical Catholic University of São Paulo, São Paulo, Brazil \\ Email: geust2007@gmail.com, analuciamanrique@hotmail.com
}

Received 5 February 2014; revised 5 March 2014; accepted 12 March 2014

Copyright (C) 2014 by authors and Scientific Research Publishing Inc.

This work is licensed under the Creative Commons Attribution International License (CC BY).

http://creativecommons.org/licenses/by/4.0/

(c) (i) Open Access

\begin{abstract}
In the face of the lack of research that investigates the relations between Mathematics teachers and students with special educational needs, an investigation was launched with the aim of identifying the social representations that these professionals have regarding disability, in addition to learning about their knowledge, opinions and doubts on this theme. The research was carried out with the participation of 65 mathematics teachers and data collection resulted from replies given to three proposed situations in an interview. Collective subject discourse methodology was used, with social representation Theory employed as a theoretical-methodological reference. The results showed the presence of distinct representations concerning the theme, with attitudes that range from support and incentive for the inclusion of students with disabilities, with evidence of knowledge of the theme, to representations that revealed the manifestation of doubts, opinions and attitudes, with positions contrary to the philosophy of inclusion.
\end{abstract}

\section{Keywords}

Inclusive Mathematics Education, Special Educational Needs, Social Representations, Mathematics Teachers

\section{Introduction}

Approaching two themes so rich and, at the same time, controversial, represents a challenge to our studies, since

How to cite this paper: Moreira, G. E., \& Manrique, A. L. (2014). Challenges in Inclusive Mathematics Education: Representations by Professionals Who Teach Mathematics to Students with Disabilities. Creative Education, 5, 470-483. 
both Inclusive Mathematics Education and Social Representations are searching for their locus in the academic environment, even though they are part of daily life in mathematics classes in Brazilian public schools. Talking about Inclusive Education in Mathematics classes, which leads us to talk about Inclusive Mathematics Education, seemed somewhat utopian.

However, we understand that, through the Social Representations of Mathematics teachers of students with disabilities, we can understand how these professionals deal with students with special educational needs (SEN) in their lessons (Correia, 2008c; Fonseca, 2008), since there has been a lot of discussion of the methodological difficulties encountered by educators who work with these students, in addition to the efficiency and efficacy of Inclusive Mathematics Education.

Although the great part of the school community recognizes that the educational practices of Mathematics teachers and the development of students with SEN are intrinsically superimposed, there are several difficulties that interfere with the existence of a relationship which should benefit everyone involved in this process.

It is necessary, nonetheless, for teachers to realize the importance of there being educational practices capable of positively stimulating the development of the student, (Yow, 2012), as well as the student with a disability. Furthermore, we emphasize that from this perspective, students with a lesser or greater degree of disability are not unable to learn, since a student who appears different because of a disability, is not a child less developed than his/her peers, but is one who has other characteristics (Vygotski, 1997).

In the face of the relevance of research that involves the Social Representations of Mathematics teachers, with the phenomenon of disability as its central concern, we prioritize the following aim: to identify and present the Social Representations that mathematics teachers in four public schools in São Paulo have regarding disability.

However, the lack of research involving the teaching of mathematics to students with disabilities must be stressed, leading us to propose a second aim, which emerged, not by chance, from the first, but sits in a more restricted context: to identify what knowledge, opinions and doubts these Mathematics teachers have regarding this theme, in the context of this investigation.

We seek to localize the set of values that the participating mathematics teachers use to anchor their Social Representations on disability. It is important to keep in mind that the overlapping knowledge and the beliefs, and skills shared by a community are acquired through social interaction and are internalized according to the historical and cultural interests of a society (Saraiva, 2005).

For Tardif (2002), knowledge (professional, curricular, experiential and disciplinary) goes beyond mere reproduction and transmission of content, resulting in an interactive activity in the space where social actors perform with each other, making their actions worth something (argumentation), assuming forms of institution and intellectual representation (subjectivity), turning a determined phenomenon into a truth.

Looking for answers to these aims means contributing to the didactic-pedagogical (re)organization of mathematics teaching (Borasi, Fonzi, Smith, \& Rose, 1999), especially for classrooms containing students with disabilities, since the social actors involved in this process need clarification and help regarding the pedagogical support for students who, up to a short time ago in Brazil, did not attend regular classes. Additionally, it is an opportunity to reflect on the complex theme of Special Education (Correia, 2008a, 2008b), above all concerning the philosophy of inclusion (Danforth \& Rhodes, 1997).

In this sense, it is necessary to be clear that the educational aims directed to the learning of so-called normal students (Rapoli et al., 2010) must be the same for those with some SEN, considering that development in these students could otherwise be slower, without the standardization demanded by schools and society in general (Vygotski, 1997).

\subsection{Reflections on Inclusive Education}

The concept of disability emerges from the specialized bibliography on the development of students with special educational needs. Among historically recorded definitions, we observe that there is no single concept that represents a position with which to face the battle of prejudice against disability. However, we know that support for students with uncommon development, still surrounded by segregation and discrimination in Brazil, has shown a tendency to place itself in favor of the acceptance of concepts that consider the social, historical and cultural development of the student in Special Education.

The historical-cultural concept of disability proposes a different approach to the existing theories on the development of students with these characteristics. According to Vygotski (1997), disability is seen as a socially 
constructed phenomenon, reported in interpretations that seek homogeneity, the labeling and classification of individuals with SEN. Martínez (2009) accentuates that Vygotski's contribution also brought an important practice for the outlining of educational strategies and actions concerning the problem herein presented, for the historical-cultural concept of disability conceived new conceptualizations for the understanding of the processes of learning and the development of individuals with disabilities, in addition to furnishing several possibilities of understanding the stages of development in children with SEN.

For Vygotski (1997), a child with a disability is not obliged to develop in the same way as his/her contemporaries. This child develops in another way, in a different way, that is, development is qualitatively different to that of other children in regular classrooms. According to Vygotski, on choosing the line of least resistance, many professionals do not consider the differences presented in the development of children with disabilities, even though it is necessary to follow the regularities found both in the child with SEN and those in regular classrooms. It is clear that the school must foresee the reaching of the same educational objectives, considering only that, in those children with disabilities, their development will be in a different manner.

At the same time, he makes considerations on collectivity and affirms that this is the basis of the development of the high psychic functions (thought, language, memory and attention), for it is through time spent with others that social life emerges, with overlapping emotions, games, social rules and every type of situation exposed to those who live in society. According to Pino (2005), a type of transposition of the experiences lived collectively to those that are individual occurs.

That is, collectivity is able to transfer knowledge that would not be possible in social isolation. According to Moysés (1997), by emphasizing the importance of social interaction for the development of the superior psychic functions, Vygotski made new perspectives possible for the study of group activities.

For Leontiev (1978), it is imperative to consider that the process of appropriation is a result of effective activities created by the development of human culture. For him, communication and interaction are only possible in a collective environment, since students are not alone in the world around them, or rather, their relationships with the world are based on their relationships with others, whose activities are inserted in verbal or mental communication, which is a necessary and specific condition for the development of those who live in society.

However, Borges (2002) points out that the teachers who work with students in the classroom generally complain about their inabilities to deal with children with SEN, the difficulty in integrating them into group work, in the sense that they can show satisfactory academic performance. For this author, such an attitude makes these students forgotten in the classroom, whose objectives do not revolve around the their educational development, which can halt their learning, leading to the labeling that the special student is less able.

Tunes (2003), on the other hand, gives more emphasis to the situation and states that it is very common to hear people say that they do not feel prepared to deal with SEN students. For her, we really are not prepared, since, if we were, our commitment to these students would not be seen as a challenge, which denotes our ineptitude regarding how to go about it. Finally, Tunes affirms that we have to seek ways of preparing ourselves, investigating, discovering, querying the fact the question to be asked is not whether we are prepared or not to deal with a Special Education student, but whether we really want to accept that the student be treated as a challenge.

According to D'Ambrosio (1998), insufficient teacher training, especially for those who teach Mathematics, is a challenge for Brazilian education. He feels that the lack of training in getting to know the student and the outdated content acquired during teacher training, constitute the need for change in the curriculum, mainly Mathematics, to give these professionals the opportunity to value their students' experiences. For Correia (2008a), the academic demands in dealing with an SEN student increase the frustration and anguish of teaching staff, meaning that their training must be more appropriate. Moreira and Manrique (2012a) point out that teachers have been increasingly seeking ways to fill the gaps in their initial teacher training, by means of continuous training. According to researchers, teachers have been looking for this type of continuous training to make themselves more equipped to the demands required when dealing with SEN students, thereby trying to minimize the impact related to the learning of these students in Mathematics classes.

Although the majority of teachers believe in inclusion, Correia's research (Correia, 2008a) shows that teachers have some reservations related to the changes that Education has been undergoing, especially because they feel the lack of the training necessary to teach SEN students. On the other hand, Tunes et al. (2005) stress that for the teacher ready to promote student learning, it is necessary to penetrate and interfere in their psychic activity. For Tacca (2007), some attitudes are necessary to help teachers to develop their work, such as attentive, daily intervention, with a view to placing their personal resources and different instruments and educational strate- 
gies at the service of the learning and development of the SEN student.

As a way of correcting such distortions, Correia (2008a) points out that continuous training of teachers, which should be offered by universities and peers in an educational context, taking into consideration the needs of the professionals, aiming for a break with the unprogressive inclusive school, is an attitude that can help solve the problem. Thus, according to Torezam (1999), in a general way, this change in schools presupposes measures that alter, among other things, the negative concept of disability as a problem inseparable from the individual.

In accordance with the philosophy of inclusion, using human solidarity, the professionalism of teaching staff and knowledge of the needs of others as guidelines contributes to the socio-emotional development of everyone involved. By getting to know their students, Special Education teachers help in the construction of ideas and the development of concepts in a more schematic way. For Ponte and Oliveira (2002), it is necessary to get to know our students as people, learn about their interests, what they like, how they react to a certain action, to know what their values and habits are, among other characteristics. Thus, knowing the student, the teacher will be better able to carry out activities satisfactorily. In this sense, the teachers recognize the importance of understanding the students' learning processes, their cognitive difficulties, their micro-social strategies, as well as their cultural interests.

This type of educational approach, which prioritizes the interaction of one subject with another and with the social environment, aiming for the development and improvement of psycho-pedagogical skills, reveals the social aspects of inclusive learning, in addition to meeting the organic, emotional and social needs of SEN students.

While he does not refer to the education of SEN students, much less to specific learning difficulties (SLD), we agree with D'Ambrosio (2000), since students and their respective teachers should grow socially and intellectually in the process, regardless of the degree of difficulty presented by the student. As such, it is necessary for teachers, the main actors involved in the democratic inclusion process, to know the socio-cultural demands that appear in the development and the education of the special needs student.

We know that the redefinition of the strategies used to train teachers, both in and out of the school environment, has offered several initiatives, which reveal the need to make more visible the constructive process of pedagogical practices capable of transforming the current school reality (Esteban, 2002; Ezpeleta \& Rockwell, 1986; Young \& Curcic, 2013). In this sense, the school can adopt a different attitude in the face of the barriers imposed by disability, proposing pedagogical practices focused on respect for individuality, demystifying the belief that the student with uncommon development is incapable of learning and developing.

Esteban (2002) discusses Vygotski (1997, 2001, 2007) and reflects that the exploitation of the potentiality of school reality must occur as the individual trajectory is replaced by collective paths. This does not mean abandoning individualism, singularity. It means enriching subjectivity, through the establishment of networks of solidarity, since the final objective of school does not consist of adapting to disability but of overcoming it in a positive way (Vygotski, 1997), with the help of teachers who accept the challenge and who are prepared to deal with diversity.

\subsection{Social Representation Theory (SRT)}

Moscovici, speaking against the excesses of individualism present in Social Psychology, sought a conceptual shelter for the discussions that led to the creation of his Durkheimian theory, proposing a narrow relationship with his collective representations. For him, modern society's characteristics were pluralism and the speed at which changes occur. In this sense, few representations are effectively collective.

Later, the development of SRT constituted its own psycho-sociological field, moving away from the sociological perspective. According to Serge Moscovici (1978), Social Representations constitute a set of concepts, propositions and explanations rooted in people's daily life, in interpersonal communication courses. They are equivalent, in our society, to the myths and belief systems of traditional societies, and, furthermore, can also be seen as a contemporary version of common sense.

For him, social representation refers to the way the individual thinks and interprets his/her daily life. Similarly, Abric (2001) states that social representations are instantaneously determined by the subject himself, through his history and experience, by the social and ideological system in which he is inserted and by the nature of the links the subject maintains with the aforementioned social system.

One of his main collaborators, Jodelet (2001), enriches and widens the concept of social representation, with a 
definition that is the most accepted among researchers in the area. For her, it is a specific form of knowledge, socially developed and shared, with a practical aim, and which contributes to the construction of a common reality for a determined social group. Known as common sense or simple, natural knowledge, it is a type of knowledge different to scientific knowledge. However, it is an object of legitimate study, due to its social importance and the way it facilitates clarification of cognitive processes and social interactions.

Jodelet (1984) considers that Social Representations tell us about the way individuals learn what happens in daily life. She also adds that they are modalities of practical thought, that they lead to communication, understanding and the mastery of the social, material and ideal environment. They thus present specific characteristics in the representation of the organization of content, of mental operations and of logic.

For her, Social Representations, which reveal a model of sociocentric knowledge, are approached at the same time as a product and as a process of activity of appropriation of reality outside thought and of the psychological and social development of this reality.

The processes that demonstrate the interdependence between psychological activities and their social conditions of being exercised, called objectification and anchorage, were responsible for the formation of social representations and serve in the transformation of the non-familiar into the familiar, the unknown into the known (Moscovici, 1984).

The materialization of these ideas and concepts is effected in the process of objectification, which is responsible for conferring a familiar scenario on what was strange (Horochovski, 2004). For Moscovici (1990), objectifying is nothing more than reabsorbing excess signification, through materialization and the search in the living world for what was just a word or symbol, for mental states are not fixed in the individual. They are projected, take form, are directed towards being consolidated and becoming objects. In this sense, the passage of concepts and ideas for schemes and concrete images occurs.

Discussing Moscovici and Jodelet (1984) goes further and states that objectification is a process of the formal construction of knowledge, which guides individual perceptions and judgments in a constructed reality, but which does not guarantee the organic insertion of this knowledge. According to the author, in this process the individual re-absorbs an excess of significations, materializing them, which is the above mentioned formal process of construction of certain knowledge.

On the other hand, the second process of the formation of social representation, anchorage, seen as a penetration of a new representation into those that already existed, is what gives the eminently social character to the representations. Anchorage, on a two-way street with objectification, guarantees the absorption of the knowledge and of new concepts through the three central functions of representation: the cognitive function (acts in the integration of new knowledge), the interpretive (interprets what is real) and the orientative (guides conduct and social relations).

For Moscovici (2005) it is in anchorage that it is possible to transform the unknown into the known from existing knowledge. Anchorage is directly related to beliefs, values and attitudes. For Jodelet (1984), anchoring means cognitively integrating a represented object (feelings, actions, ideas, people, relationships) into a system of social thinking.

By proposing these reflections on SRT, emphasizing the process of anchorage, we thus intend to significance to the beliefs, doubts and values of the interviewees who teach Mathematics to SEN students, in other words, bring the unknown object from anonymity, placing it inside the culture of these professionals (Moscovici, 2005).

\section{Methodology}

\subsection{Research Design}

Concerned about the nature of our object, which is empirical, in addition to the theoretical system which underlies and legitimizes our study, we opted for the utilization of Social Representation Theory (Moscovici, 1978, 2005) as the theoretical-methodological axis, allied to qualiquantitative research (Lefevre \& Lefevre, 2010).

In Saraiva (2005), we found the justification that sustains our theoretical-methodological option. According to her ideas, Social Representations offer great interpretive potential as an object of study considering their theoretical capacity, since this is able to elucidate the socially produced system of signification embedded in the group and shared among individuals.

Nowadays, there has been a lot of discussion about the inseparability of research of a qualitative or quantitative nature. The association between these two forms of producing knowledge has gained followers, mainly be- 
cause it associates the positive side of qualitative research to the qualities of quantitative research, opening space for what has come to be called qualiquantitative research (Lefevre \& Lefevre, 2010).

In this type of research, collective opinions reveal qualitative and quantitative dimensions concurrently, generating manifestations on the theme being investigated, whose qualiquantitative characteristics have incorporated a new methodology of investigation, which has come to be called Collective Subject Discourse (CSD), with its foundations in SRT and in sociological presuppositions. Moreira (2012) makes it clear that CSD is the collection of Key-Expressions in different statements, with similar meanings, brought together in the same Central Idea Category or Anchorage, in one single discourse.

According to its creators, this is an essentially qualiquantitative method. During and after the research, the essentially discursive and qualitative nature of the opinion or representation was preserved, the case being that, inseparable from the representation, we have the quantitative dimension, which is associated to the representativeness and generalization of the findings.

Using SCD, it is possible to identify the ideas, beliefs and common values shared by a certain social group, in relation to a determined subject, as pointed out in Moscovici's Social Representations (1984).

The analysis of the discourses is carried out by means of the identification of central ideas and key-expressions, with similar statements grouped together, forming a discourse synthesis, written in the first person singular, since the Social Representations expressed are at the same time individual and collective expressions (Lefevre \& Lefevre, 2010), that is, a subject able to represent the discourse of collective thought, revealing that when the individual thinks, it is also the social group that is thinking through him/her.

According to the authors, CSD as an empirical research proposal is appropriate for the reconstitution and description of collective opinions, beliefs, and representations and is also sociologically possible and methodologically necessary, since collective thoughts and representations can be described and presented.

\subsection{Sample}

Considering the theoretical field that sustains and justifies our study, as well as its scope, we needed to work with a larger number of subjects. 65 in total, with 55 female and 10 male, who teach Mathematics in four public schools in São Paulo State. The four schools were chosen as each one has a staff member participating in the same Project to train the teaching of Mathematics to students with a disability. In the sample, we encountered teachers between the age of 20 and 63. Teaching experience, however, varied between 1 and 43 years.

\subsection{Data Collection Instruments and Process of Data Collection}

The procedures adopted during the interviews followed guidelines set out by Bauer and Gaskell (2000), who considered it fundamental to emphasize the confidentiality of the data collected and of the interviewee. According to the authors, this leads the participants to give consistent responses, generating a relationship of trust between the interviewee and interviewer.

Three everyday situations in basic education schools were proposed to the teachers interviewed for them to answer the question proposed in each situation. The function of each one of these situations was as a thematic trigger so that the teachers could focus their opinions.

Situation 1: In this thematic trigger, our aim was to learn about the opinion of the teachers interviewed regarding relationships established between students in regular school and special needs students, as well as identifying possible beliefs and myths concerning the education of students with a disability.

"Maurício and Natalia are friends. They are Middle School students in the same class. They often do Mathematics activities together. But this has been worrying the Mathematics teacher, Vagner, because Natalia does the activities for Mauricio, who has a disability. If you were Vagner, would you have the same concern? Why?”

Situation 2: The aim here was to check the opinions, attitudes and behavior of the teachers interviewed after facing an instance of prejudice in a Mathematics class. "In a city public school, several students meet each other again and others come from several different regions. It's a moment to catch up with old friends and make new ones. In a Middle School Mathematics class, which is the first class of the day, a new student arrives, Bruna. Carla knew Bruna when they studied together. Suddenly Carla says:

Oh no, not again! I used to study with this disabled girl and she disturbs the lesson all the time... Before Carla can finish, the teacher, Catarina, interrupts her and says to her and the other students that... 
If you were in Catarina's place, what would you say to Carla and the other students?”

Situation 3: Finally, we exposed the interviewees to a situation whose aim was to reveal the concepts that the teachers involved in the research have regarding the phenomenon of disability.

"Felipe studies at Middle School. He is enthusiastic about his teacher and new classmates that he has just met. Despite not understanding well, he has noticed that one of his classmates, Caio, is different. The other day he heard the teacher say that Caio is disabled. Felipe can't stop thinking about this and he wants to know what it means. At a given moment, he goes to the teacher and asks what disabled means... If you had to explain to Felipe what a disability is, what would you say to him?”

After the definition of the data collection instrument, we held meetings with institutional managers, in which we presented our plan of studies, the aims of the research, the interview scripts. We requested authorization to collect data inside the teaching units. Once authorization was obtained, we adopted similar procedures for the mathematics teachers. The staff were invited to participate in the research, the interviews were given individually according to their availability and were recorded.

For Esteban (2002), the aim of educational research is the improvement of teaching practice, where the connection of this with theory furnishes the transformation into reality. Thus we understand that methodological design must favor the dynamic of the educational process, acting in the historical-cultural construction of an education capable of respecting the individuality present in school diversity. By using an interview as the data collection tool, we guaranteed the reliability and precision of answers obtained, as well as supplying conditions conducive to the flow of the Social Representations of the individuals who participated in the research.

\subsection{Analysis of Qualitative Data}

Data concerning Situations 1, 2 and 3 were analyzed qualiquantitatively. The qualitative part of the analysis was done using the interview responses as they were given, initially favoring dynamic reading and later using Qualiquantisoft software. The analysis was carried out by means of CSD methodology (Lefevre \& Lefevre, 2011a, 2011b), with RST (Moscovici, 1978, 2005) used as a theoretical-methodological reference. The semantic diversity and plurality of the different attributes reached by the breadth of the representations were also considered (Lefevre \& Lefevre, 2005).

We adopted several methodological safeguards during the procedures of treating the data so as to guarantee precision in the extraction of the Social Representations of the study participants, paying attention to the identification of the discursive plurality of collective thinking.

\section{Results}

In this study, we prioritize the investigation of the concerns, opinions and knowledge of the interviewees regarding the phenomenon of disability, given its unarguable importance as a promoter of the socio-cultural relations acquired in the process of inclusion of students. Thus, the contextualization and the reflections on Social Representations that teachers have concerning the theme, the epistemological statute of the research and the detailed study of the discourse of the participants make up the kernel of the discussions that orient the response presented in the distinct situations.

In the following pages, we present the participants' discourse, organized in CSD, encountered in the three proposed situations, in a way that allows for a general and globalized view of the interviewees. The appearance of a variety of social actors was a surprise for us and revealed that there is no uniformity of opinion among those professionals involved.

Table 1 contains the CSD, with the respective Social Representations regarding the first situation, whose aim was to learn about the interviewees' opinions on the friendship and companionship between the two students in Mathematics classes: Natalia and Mauricio, a disabled adolescent.

From an analysis of Table 1, we can observe that the situation presented obtained distinct CSD, with their respective Social Representations: six in total. In our understanding, the Social Representations are not unconnected to the statements of the social actors that produce them and are reproduced in their socio-cultural universes. In this sense, we opted to construct a dialogue between the researchers and the statements made by the interviewees, in their respective schools which, from a theoretical-methodological point of view, enriched the research, since the CSD is founded in SRT presuppositions, able to show us what we were seeking: the beliefs, doubts, knowledge and opinions of those interviewed. 
Table 1. Collective subject discourses on Situation 1.

\section{Collective subject discourse}

I would not be worried. The disabled student feels insecure alone and the fact that Natalia helps him does not mean that she is doing the work for him. Knowledge is built up together and it's easier that way. I would guide Natalia not to do things for

1 him, but to help him, monitoring their activities closely. Actually, I think it’s laudable that a student would want to help and would do activities with a disabled classmate, because in most cases students refuse to do activities with such students, claiming that they don't make any contribution.

I would never worry about this. I would take a very relaxed position because working in pairs shows amazing results! Besides Natalia helping Mauricio, social interaction is taking place between the students. This interaction between them, the partnership, the collaboration benefits both! I think the socialization and interaction of a person with a disability are more

2 important than their answers. For me, being together is more important than doing the activity, because most of the time the help from classmates improves academic results and performance, and very often a teacher does not manage to reach all students. This way, the students would have the opportunity to work with other classmates, developing their autonomy. If the student manages to relate with a classmate during activities, in my view that's a good start.

I wouldn't be worried. Perhaps the student is helping her classmate with his problems. But, through activities and over time, that student might come not to need his classmate's help. We have limitations and it would be good if the teacher, could help the student by using activities, changing his routine, using other resources so that he can develop his knowledge. I believe that 3 a student with a disability is also a capable student. Vagner, the teacher, should worry more about getting to know Mauricio better so as to learn what he is capable of and what his problems are, believing that anything is possible and that everyone is intelligent and competent. The aim is that both learn, even from differences. If I noticed any hold-up in the activity, I would spend more time on explaining the question.

Yes, I would be concerned. The teacher should observe if the student really is doing the activities for him. He can be helped and guided but a classmate should never do the work for him because Natalia thinks she is helping Mauricio, who cannot learn because of his disability. And Mauricio could also be a little uncomfortable with the situation, and Vagner should talk to

4 Natalia and clarify the ways of helping. If she does the work for him, this stops him thinking, trying, learning. His learning would be jeopardized. So, he feels complacent, apathetic, and this will jeopardize him, because he is being carried by the others, who feel sorry for him and so do the activity for him.

Oh I would be worried, because Mauricio would be evolving very little if his friend Natalia did activities for him, because this impedes his academic performance and he wouldn't know if he was managing to keep up with the class. Mauricio needs to find his own way, feeling self-confident, to conquer his fears to walk on his own two feet, facing and accepting his difficulties, because in this way he will be able to walk more confidently to overcome his difficulties and feed his self-esteem.

5 By separating them, I will know how to identify the development and ability of each student while doing the activity and when it's a question of a disabled student, the teacher should accompany him according to his needs. He should give different activities, alternating between individual, pair and group activities so that it will be clear how much the student has advanced and what still needs to be improved.

Yes, I would be worried, mainly if the student were more advanced in the level of learning. After a "diagnostic evaluation" with a professional, I would check the different forms of interaction between the children and the result of the diagnosis.

6 Special students need to have their own school. They disturb our classes and don't allow the others to learn. The disabled student is not equipped to study with others and I think the government is putting these disabled students in with the others because if they don't pass, the others carry them.

The Social Representations of the participants who showed themselves to be favorable to the explicit situation presented few differences in their make-up, but significant differences from the point of view of collective subject discourse, which favored the analysis of the social field researched (Lefevre \& Lefevre, 2010). They did not reveal concerns about Mauricio and Natalia being together, which can be seen from the references to "knowledge is built up together" (CSD 1), "the socialization of the person with a disability and his interaction" (CSD 2) and "the aim is that both learn, even from differences".

For Correia (2003), the attitudes of the teachers have a strong influence on the harmonious insertion of Special Education students into regular classes, since, if these attitudes are not appropriate, the regular class students quickly become less receptive to the acceptance of classmates with special educational needs.

In this sense, consulting the theories on the historical-cultural development of the SEN student proposed by Vygotski (1997), we find strong indications regarding the teachers who have some knowledge of the processes of inclusion and who believe in the potential of the student with a disability. Having control of classroom situations was one of the characteristics present in the social representation of the interviewees in CSD 3. They not only supported the continuance of the friends working together, but also displayed confidence in the development and ability of the disabled student. 
On the other hand, the discourses present in the Social Representations of the participants who demonstrated a similarity between what they said and Vagner's thinking show opinions that go against the inclusion of the SEN student. The protagonists of CSD 4 and 6 remind us that the current social organization, present in the Mathematics class and in contemporary Brazilian society, contributes to the reinforcement of the segregationist idea regarding disability: "cannot learn because of his disability" (CSD4) and "special students need to have their own school" and "the disabled student is not equipped to study with others" (CSD 6). These go against all the actions that seek to legitimize the inclusion of disabled students in Mathematics classes.

Moreira and Manrique (2012b) carried out research involving a similar theme. In their investigation, it was shown that these teachers need help and clarification of the theme is required, especially when their attitude in the situation, sometimes indifferent, sometimes welcoming, promotes or inhibits the process of inclusion of the SEN student. However, this situation does not block the possibility of pedagogical work being carried out that is able to take into consideration the differences present in the classroom.

For Correia (2003), the concept of inclusion should not be considered as something fixed, set, but should allow for a set of options to be considered whenever the situation demands flexibility.

As an example of this, we find healthy Social Representations regarding the phenomenon of disability in CSD 5. The social actors believed in a series of attributes related to the stimulation and confidence of Mauricio: "feeling self-confident, to conquer his fears to walk on his own two feet, facing and accepting his difficulties".

In situation 2, the interviewees were faced with an instance of prejudice taking place in a Mathematics class, whose protagonists are two students, Bruna, who has a disability, and Carla, and their teacher Catarina. Our aim was to check the opinions, attitudes and behavior after encountering such circumstances. Their collective discourses can be found in Table 2.

By what can be observed, there is a very great semantic proximity between the thematic content of the Social Representations, with the exception of CSD 4. By revealing a position of combat against the situation of the prejudice experienced, they demonstrate support for the inclusion of students with a disability, reinforcing the idea that students should study together, that everyone has equal rights, as laid down in Brazilian law, and that respect for diversity and individuality are fundamental for social development. Accordingly, distinct authors have been worrying about the exclusive character of special education and about the inclusion of the SEN students. They point out that the concept of disability has evolved, assuming connotations that seek to value the SEN student (Moreira \& Manrique, 2012c).

In contradiction, the discourses present in the fourth representation, while affirming the same rights for all present in that environment, label Bruna as a "special needs student”, point out her "inabilities" and, against any attitude that seeks to break with prejudice, give credit to segregation: "because this government is making everyone study together, but these children don't even know how to use the bathroom”.

To escape further questioning, they try to justify their position, "it's not that I'm against inclusion, but some of them can't keep up and also their problems do disturb the class a little”, causing even more revolt against those who are favorable towards the philosophy of inclusion. The main aim of getting to know a student is to analyze their potential for development and learning, evaluating at the same time what educational resources are necessary for learning (Marchesi \& Martín, 1995), and not to speculate on their difficulties or segregate them from the group.

We can clearly note the lack of knowledge, of clarity and the sense of belonging to a social group of individuals with affective and normative implications (Jodelet, 2001) and the disdain for the student with a disability. Borges (2002) points out that the lack of preparation of some teachers in dealing with Special Education students is not uncommon. However, Nielsen (1999) questions these affirmations and points out that the basic needs of an SEN student are the same as those of a student in regular school. For this researcher, emphasizing the existing similarities is essential to promote positive interactions between all the students.

Finally, in the third thematic trigger, the teachers interviewed had to explain to Felipe, a student in one of the early years of Middle School, what disability is. Table 3 shows the collective discourses for the problem in question.

According to the representations seen in the first discourses, there is a tendency to position themselves in favor of the concepts that value disabled students, which can be observed in the statements, since "the person has some kind of difficulty that's different from others, which does not stop him from learning, working or living" (CSD 1) and "this does not make us better or worse than anyone else" (CSD 2). While in CSD 1 the Social Representations of the teachers indicate knowledge of the concept of disability, "it is when something is not at the 


\section{Collective subject discourses}

I would say that actually we all have disabilities in specific areas. Sometimes a student is unable to understand a certain content and is ashamed to ask, and so becomes disabled in the subject. I would say that there are no disabilities, but special ways and

1 conditions of learning and that Bruna is a different student, though as normal as anyone else. We have the same learning objectives and her performance would certainly be better than normal. We are equal in this classroom. We will treat others as we would wish to be treated. We are all different, some are brown-skinned, others white, and each one has their importance.

I would stop the lesson and make it clear that the fact that Bruna has difficulties and limitations does not mean she is incapable. I would first ask Carla what disability is and then what she means by disturbing the class. I would then demonstrate how much it hurts to be labeled. I would take opportunity to ask everyone to collaborate and welcome Bruno with affection, regardless of her needs. Each person in the world is different from the others, each one has qualities and needs that must be recognized by classmates. Each human being has their peculiarities and individualities and these must be respected, valuing intellectual and physical development and many other things and I do not accept prejudice from intelligent people. I would also say that she is a special child, not a disabled one and that when she does something wrong they should guide her towards doing it right (teaching). I would say that we have to respect the differences of others and learn how to live with them, for nobody is the same as another, and that maybe she can help us and that being together enriches the group. I would also try to place the student with other students in dynamics where the priority is socialization and inclusion. I would draw attention to the role of each one in society in general, highlighting the importance of diversity, because we can always learn from and help each other. I would remind them that every human being, disabled or not, has their limitations and that differences should not be a barrier to coexistence, but a way of learning more from others, often putting yourself in their position.

I would clarify her disability, or rather, limitation in doing some things that we do more easily, that she has special needs. That despite her handicaps, she has the same rights as her classmates and she is not to blame for coming into the world as she did. But

4 I also agree a little with Carla because this government is making everyone study together, but these children don't even know how to use the bathroom, in some cases. It's not that I'm against inclusion, but some of these can't keep up and also their problems do disturb the class a little.

I would tell the class that Bruna had every right to attend or visit the school and to have everyone's respect, without prejudice and I would say that she had a lot to contribute to make them better people. I would speak for equality in a school context, and

5 would say that the limitations of her disability did not stop her from learning or rob her of the right to live in a community. Finally, I would say that discrimination is a crime, punishable by law, and that it was highly likely that Carla also disturbed lessons now and again, and that she had no right to speak about anyone else.

\section{Table 3. Collective subject discourses on Situation 3.}

\section{Collective subject discourses}

Disability is when something is not at the level of normality expected by society. It means that a person has some kind of difficulty that's different from others, which does not stop them from learning, working or living like "normal” people. They

1 have trouble moving around or doing homework, and need help from classmates. For some reason, the person was born with this problem or had an accident and so loses some skills, like thinking and speaking, or a limb: a leg, an arm which stops them from being able to act like others or the student is simply born with a problem, which can be physical, mental, or both.

I would say that to be disabled is to be normal, or to put it better, "it’s normal to be different". That his friend Caio is a child like

2 any other, it's just that he has a different rhythm and we have to work together, helping him so that he learns too and participates 2 in all activities. That he is different with a different way of learning, to the point of needing special attention and care and that
this does not make us better or worse, and that is why it's important that everyone is treated with respect.

Disability means not being able to do things that others can do. The person is also different, he/she has more difficulty 3 understanding what you understand quickly. They are people who have certain limitations, but even so they are our friends, with their own peculiarities, like everyone else. Disability interferes with their development in all activities and learning. A disabled person will not be able to carry out a certain activity due to his/her physical or mental condition.

I would say that disability is something very bad that jeopardizes people and the families of disabled people suffer a lot. They

4 have to do everything for them, adding that they cannot even feed themselves. We have to thank God that we do not have this affliction.

5 I would not know how to give a child an answer to this. Despite working in a school that has these students, I cannot deal with them and I don't really know how I would act.

level of normality", of its impact, ,"living like "normal” people”, and its causes, "the person was born with problems or had an accident", in CSD 2 their knowledge of the theme is more at the level of the meaning of disability: "being different, with a different way of learning, to the point of needing special attention and care". Similarly, Moreira (2012) states that when teachers refer to disability in terms of attributes that value differences, 
manifested in their representations, they disseminate positive ideas in relation to disability and inclusion, creating an environment favorable to the processes of teaching and learning.

However, it was verified in the two following discourses that there is a lack of clarification in those involved in the investigation. Explaining disability as "not being able to do some things" (CSD 3), as "something very bad" and "thank God that we do not have this affliction" (CSD 4) reveal the enormous problem that Inclusive Education in Brazil is still facing in being legitimized. In these Social Representations on disability we have the reflection of prejudice and exclusion, in existence since the first inclusive movements and that have tended to be perpetuated until today (Diaz, 1995). This type of thinking, spontaneous and authentic, is predictable when we work with CSD methodology, since the social actors manage to step outside politically correct responses, expressing their real feelings (Moreira, 2012).

The responses that resulted in the statements seen in the Social Representations in CSD 5 and 6 of Situation 1, CSD 4 of Situation 2 and CSD 4 and 5 of Situation 3 put us in a position of questioning and at the same time of responsibility for Special Education, since we have the possibility of interfering in these situations, seeking to contribute to the effectuation of the process of inclusion of students with disabilities, and other minorities, both in Mathematics classes and other school situations.

In the statements made by some of the interviewees, it is possible to observe the attribution of various negative characteristics or concepts to students with a disability, associating them with individuals who are incapable of developing and learning, and that they do not belong to the social group in which they have been placed. For Moscovici, according to Jodelet (2001), by representing something, we create and transmit a product progressively elaborated in countless places. In this sense, the proliferation of retrograde ideas concerning the philosophy of inclusion could represent a threat to the advances made.

In the different Social Representations expressed, we observe the repetition of ideas and attitudes in several discourses, some with greater intensity, others with less frequency. The interviewees, in the main, revealed their representations, which were diversified, as embedded in distinct social universes, constructed from their experiences, habits and social interaction.

\section{Conclusion}

Since the decision as to the theme of investigation, we have learned much about the potentialities of inclusive education, its emancipative and constitutive processes, the legitimization of the social actors who fight for and seek equality of rights for everyone. And, through the many dialogues held with the social actors in this investigation, it has been possible to interpret and understand the diverse Social Representations, manifested in distinct forms by the group, as well resignifying many of their statements, prioritizing the existing knowledge in each one and in all.

The thematic triggers presented, seen by us as very simple, showed themselves to be complex, leading to immediate implications in the execution of this research, for we came to observe the direct and indirect manifestations that influenced the interviewees, whose opinion diversified, culminating in the immediate appearance of several "collective subjects", which, are, in fact, a form of directly expressing Social Representations (Lefevre \& Lefevre, 2010), defined using cognitive, affective, personal, interpersonal and social factors, since their processes of legitimization require the contextual conditions that overlap in the tense social relations of a determined group (Jodelet, 1984).

Supporting the formation of pairs, groups or activities that involve all the students, with or without SEN, in the regular classroom and defining and viewing disability as a constituent part of society and diversity revealed healthy representations regarding the object investigated, since the results suggested the involvement of most Mathematics teachers with these students and in the emancipative process of the philosophy of inclusion. We noted that many interviewees presented high expectations in relation to the development and inclusion of students with disabilities, responding to their individual needs, offering appropriate education, revealing that attention to diversity demands a different set of teaching strategies, capable of meeting the needs of the whole group of students (Correia, 2003).

One fact pointed out by the literature in this area and noted by us was the need for the group to receive clarification on the theme, mainly when their attitude in a situation, whether one of indifference or exclusion, promotes or inhibits the inclusion of the disabled (Moreira \& Manrique, 2012c), because the teacher, both in the regular and the special education classroom, plays an important role in the creation of a positive, enriching edu- 
cational environment for the whole school community (Correia, 2003; Borasi, Fonzi, Smith, \& Rose, 1999).

On the other hand, being concerned about situations considered typical by those who know and encourage the integration of an SEN student seems very worrying to us, requiring immediate interventions in relation to the various events that take place in the school environment, such as arming these professionals with knowledge regarding the theme, which could be done through continuous training (Moreira, 2012), making it possible to know the evolutionary profiles of the students, their limitations and difficulties, deciding whether there are organic or environmental causes for their needs (Marchesi \& Martín, 1995).

And finally, CSD methodology allowed us not only to highlight the Social Representations of these interviewed teachers, but also to obtain responses that stepped outside of the "politically correct" stereotype, tangled up in a complex network of diffusion of discrimination, prejudices and non-acceptance of what is different as a constituent of a school community that seeks to legitimize its actions in the face of the fight against attitudes like those encountered in our investigation.

The results also show that some professionals who are directly involved with Special Education students urgently need educational experiences able to combat existing prejudice in their social and school practice (Moreira \& Manrique, 2012b). Consequently, such representations reflect a backward step in advances made and solidified through actions that seek a place for minorities, as in the case of the inclusion of students with disabilities.

Similarly, the teacher needs to be able to recognize social interaction as human heritage, which needs to be refined, respecting the advances made at each stage successfully completed, contributing to the success of the stages to come.

\section{Acknowledgements}

This paper is based upon work supported by Coordenação de Aperfeiçoamento de Pessoal de Nível SuperiorCapes, Programa Observatório da Educacão, Edital 2010. Any opinions, findings, conclusions, or recommendations expressed in this paper are those of the authors and do not necessarily reflect the views of the Capes.

\section{References}

Abric, J. C. (2001). O estudo experimental das Representações Sociais. In: Jodelet, D. (Org.). As Representações Sociais. Rio de Janeiro: EDUERJ.

Bauer, M., \& Gaskell, G. (2000). Pesquisa qualitativa com texto, imagem e som: Um manual prático. Petrópolis: Vozes.

Borasi, R., Fonzi, J., Smith, C. F., \& Rose, B. J. (1999). Beginning the processo of rethinking mathematics instruction: A professional development program. Journal of Mathematics Teacher Education, 2, 49-78.

http://dx.doi.org/10.1023/A:1009986606120

Borges, E. T. (2002). As concepções de professores acerca da deficiência mental. Dissertação de Mestrado. Brasília: Universidade Católica de Brasília.

Correia, L. M. (2003). Educação Especial e Inclusão: Quem disser que uma vive sem a outra não está no seu perfeito juízo. Portugal: Porto Editora.

Correia, L. M. (2008a). Inclusão e Necessidades Educativas Especiais: Um guia para educadores e professores. Porgugal: Porto Editora.

Correia, L. M. (2008b). A escola contemporânea e a inclusão de alunos com NEE: Considerações para uma educação com sucesso. Portugal: Porto Editora.

Correia, L. M. (2008c). Dificuldades de aprendizagem específicas: Contributos para uma definição portuguesa. Portugal: Porto Editora.

D’Ambrosio, U. (1998). Tempo da escola e tempo da sociedade. In: Serbino, R. V. (org.). Formação de professores. Brasil, São Paulo: Editora Unesp, 239-250.

D’Ambrosio, U. (2000). Educação Matemática: Da teoria a prática. Brasil, Campinas, SP: Papirus.

Danforth, S., \& Rhodes, W. C. (1997). Deconstructing Disability: A Philosophy for Inclusion. Remedial and Special Education, 18, 357-366. http://dx.doi.org/10.1177/074193259701800605

Diaz, A. L. A. (1995). Histórias de las deficiências. Espanha: Escuela Libre Editorial.

Esteban, M. T. (2002). O que sabe quem erra? Reflexões sobre avaliação e fracasso escolar. Brasil, Rio de Janeiro: DP\&A Editora.

Ezpeleta, J., \& Rockwell, E. (1986). Pesquisa participante. Brasil, São Paulo: Cortez. 
Fonseca, V. (2008). Prefácio. In: Correia, L. M. Dificuldades de aprendizagem específicas: Contributos para uma definição portuguesa. Portugal: Porto Editora.

Horochovski, M. T. H. (2004). Representação Sociais: Delineamento de uma categoria analítica. Revista Eletrônica de Sociologia Política da UFSC, 2, 92-106.

Jodelet, D. (1984). Representations Sociales: Phénoménes, concept et théorie. In: Moscovici, S. Psychology Sociale. Paris: Presses Universitaires de France.

Jodelet, D. (2001). Representações Sociais: Um domínio em expansão. Brasil, Rio de Janeiro: Ed. UERJ.

Lefevre, F., \& Lefevre, A. M. C. (2005). Depoimentos e discursos: Uma proposta de análise em pesquisa social. Brasília: Liberlivro.

Lefevre, F., \& Lefevre, A. M. C. (2010). Pesquisa de representação social: Um enfoque qualiquantitativo. Brasília: Líber Livro Editora.

Lefevre, F., \& Lefevre, A. M. C. (2011a). A novidade do discurso do sujeito coletivo. São Paulo: IPDSC.

Lefevre, F., \& Lefevre, A. M. C. (2011b). Curso teórico-prático de introdução ao Discurso do Sujeito Coletivo e ao Software Qualiquantisoft. São Paulo: IPDSC.

Leontiev, A. (1978). O desenvolvimento do psiquismo. São Paulo: Moraes.

Marchesi, A., \& Martín, E. (1995). Da Terminologia do Distúrbio às Necessidades Educacionais Especiais. In A. Marchesi et al. (Org.), Desenvolvimento Psicológico e Educação: Necessidades Educativas Especiais e Aprendizagem Escolar. Porto Alegre: Artes Médicas.

Martínez, A. M. (2009). La perspectiva histórico-cultural y la Educación Especial: Contribuciones iniciales y desarrollos actuales. Revista Eletrônica Actualidades investigativas em Educación, 9, 1-28.

Moreira, G. E. (2012). Representações Sociais de professoras e professores que ensinam Matemática sobre o fenômeno da deficiência. Tese (Doutorado em Educação Matemática). São Paulo: Pontifícia Universidade Católica de São Paulo/ Programa de Estudos Pós-Graduados em Educação Matemática.

Moreira, G. E., \& Manrique, A. L. (2012a). Ensino de Matemática e Inclusão: Concepções de professores da educação básica de escolas públicas da Região do Minho-Portugal. $12^{\circ}$ Colóquio Internacional de Psicologia e Educação: Educação, Aprendizagem e Desenvolvimento: Olhares Contemporâneos através da Investigação e da Prática. 21 a 23 de junho. Portugal, Lisboa: ISPA-Instituto Universitário.

Moreira, G. E., \& Manrique, A. L. (2012b). O que pensam os professores que ensinam Matemática sobre a inclusão de alunos com NEE? I Simpósio Luso-Brasileiro em Estudos da Criança: Perspectivas Sociológicas e Educacionais. 04 e 05 de junho. Portugal: Instituto de Educação da Universidade do Minho.

Moreira, G. E., \& Manrique, A. L. (2012c). Representações Sociais de professoras e professores que ensinam matemática sobre o conceito de deficiência: Reflexões e intervenções. II Seminário Internacional-Contributos da Psicologia em Contextos Educativos. 12 e 13 de julho. Portugal: Universidade do Minho, Instituto de Educação.

Moscovici, S. (1978). A representação social da psicanálise. Rio de Janeiro: Zahar.

Moscovici, S. (1984). The Phenomenon of Social Representations. In: R. M. Farr, \& S. Moscovici (Eds.), Social Representations. Cambridge: Cambridge University.

Moscovici, S. (1990). A máquina de fazer deuses. Rio de Janeiro: Imago.

Moscovici, S. (2005). Representações Sociais: Investigação em Psicologia Social. Petrópolis: Vozes.

Moysés, L. (1997). Aplicações de Vygotski à Educação Matemática. Campinas, SP: Papirus.

Nielsen, L. (1999). Necessidades Educativas Especiais na Sala de Aula: Um guia para professores. Portugal: Porto Editora.

Pino, A. (2005). As marcas do humano: Às origens da constituição cultural da criança na perspectiva de Lev S. Vygotski. São Paulo: Cortez.

Ponte, J. P., \& Oliveira, H. (2002). Remar contra a maré: A construção do conhecimento e da identidade profissional na formação inicial. Revista de Educação, 11, Lisboa: Universidade de Lisboa.

Rapoli, E. A. et al. (2010). A Educação Especial na perspectiva da Inclusão Escola: A escola comum inclusiva. Ministério da Educação, Secretaria de Educação Especial. Fortaleza: Universidade Federal do Ceará.

Saraiva, A. C. L. C. (2005). Representações Sociais da aprendizagem docente de professores universitários em suas trajetórias de formação. Tese de doutorado. Belo Horizonte: Universidade Federal de Minas Gerais.

Tacca, M. C. V. R. (2007). Dificuldades de aprendizagem: Percurso histórico e novas compreensões. Faculdade de Educação da Universidade de Brasília.

Tardif, M. (2002). Saberes docentes e formação profissional. Petrópolis: Vozes.

Tunes, E. (2003). Porque falamos de inclusão? Linhas Críticas, 9, Universidade de Brasília, Brasília-DF, 5-12. 
Tunes, E. et al. (2005). O professor e o ato de ensinar. Cadernos de Pesquisa, 35, 689-698. http://dx.doi.org/10.1590/S0100-15742005000300008

Vygotski, L. S. (1997). Obras Escogidas V. Fundamentos de Defectologia. Madrid: Visor.

Vygotski, L. S. (2001). Psicologia pedagógica. São Paulo: Martins Fontes.

Vygotski, L. S. (2004). Teoria e método em Psicologia. São Paulo: Martins Fontes.

Vygotski, L. S. (2007). La imaginación y el arte em la infancia. Madrid: Akal.

Young, K. S., \& Curcic, S. (2013). Perspectives on Policy/Practice (Dis)Connection-Special Educators Turned Teacher Educators' Points of View. Creative Education, 7, 452-460. http://dx.doi.org/10.4236/ce.2013.47065

Yow, J. A. (2012). Prospective Teacher Beliefs about Liberative and Oppressive Mathematics Teaching Practices: A First Step toward Equitable Instruction. Journal of Mathematics Teacher Education, 15, 83-96. http://dx.doi.org/10.1007/s10857-011-9197-5 